\title{
RISK TAKING BEHAVIOR OF INDONESIAN BANKS: ANALYSIS ON THE IMPACT OF DEPOSIT INSURANCE CORPORATION ESTABLISHMENT
}

\author{
Moch Doddy Ariefianto \\ Soenartomo Soepomo ${ }^{1}$
}

\begin{abstract}
This paper studies the risk taking behavior of Indonesian Banking Industry, especially before and after the establishment and the implementation of Deposit Insurance Corporation (IDIC). Using common set of explanatory variables; we test several empirical models to reveal the conduct of risk management by banks. In the spirit of BASEL II Accord, this paper take closer look at three types of risk behaviors namely credit risk, market or interest rate risk and operational risk, prior and post the establishment of IDIC. We tested the hypotheses using panel data set of banks operational in period of 2000-2009. The dataset consists of 121 banks with semiannual frequency (2420 observations). Our findings show that these variables explain well the three type bank risk exposures. The implementation of IDIC alters the bank behavior albeit in somewhat different way than initially hypothesized. The risk taking responses also varies across bank types. We found that State Owned Enterprise banks (SOE)behave differently relative to the rest types of the bank. Related to size, SOE banks behave more conservative after the implementation of IDIC. On the other hand its response on conditioned capital post the IDIC implementation is the opposite; they became more aggressive. We view the public pressure on this state banks has influenced the way they manage the risk.
\end{abstract}

Keywords : Risk taking behavior, BASEL II, Deposit Insurance.

JEL Classification: G11, G21, G32, C23

1 Authors are lecturer s at Faculty of Economics and Business, Ma Chung University, Malang. They can be contacted by email at mochammad.ariefianto@|ps.go.id or soenartomo.soepomo@machung.ac.id. 


\section{INTRODUCTION}

Recent theory of banking includes risk management as core function of banks (Freixas and Rochet, 2008). The function takes a central attention especially in a volatile and fast changing today environment. Ideal management objective not only aims at maximizing return subject to resources constraint butalso reasonablerisk.

It is a well-established preposition that in the event of asymmetric information, bank managers and or shareholders preferred higher risk portfolio in the expectation of larger return. The situation is worsened when public guarantee for third party funds exists (explicit or implicitly). The latter introduced the moral hazard problem.

To overcome the problem, many authorities create a deposit insurance scheme in place of public guarantee. The mechanism may vary, nevertheless in essence it is the banks themselves that raise the funds to back up possibility of bank rush. This scheme is quite old. US Federal Deposit Insurance Corporation was established in 1933 as a response to Great Depression.

Indonesia created Deposit Insurance Corporation (IDIC) in September 2005. Its creation was proposed after 1998 crisis revealed major weakness in banking system. With the absent of deposit insurance institution, the government has to bail out the failing banks (or even illiquid banks). The fiscal cost was enormous in which estimation ranged around IDR. 600 Trillion (More than USD 60 billions).

Learning from the grim consequences, it is decided a semi public institution should handle the safety of funds and deal with the problems of bank liquidity and solvency. IDIC charges a flat rate of $0.01 \%$ based on monthly average deposits. Deposits coverage insured according to current law is maximum Rp. 2 Billions and must comply with deposits remuneration rule.

It remains to see whether the establishment of IDIC is effective in preserving public confidence to banks. Nevertheless it must be admitted that IDIC creation is a pivotal point in history of Indonesian banking industry. The largest challenge to date faced by IDIC is the bail out of Bank Century. In the midst of 2008 global crisis, this small commercial bank failed due to weak financial standing. Under the order of Financial System Stability committee, IDIC carried out the bail out of Bank Century whose cost around Rp. 6.7 Trillion (USD 750 Million).

The role of risk management is increasingly important, especially in current volatile business environment. Sub Prime Mortgage lost in US which subsequently followed by global crisis has shown that risk management in financial institution is still not adequate. The refinement known as Basel III proposal looks for stricter risk practices and higher capital as risk buffer.

Even though the issue is of paramount important, interestingly there are not many empirical searches exploring the issue especially for the case of emerging countries. In this regards we hope that this study would contribute a significant value not only for scientific purpose but also for policy making and regulation. 
In this paper we take a closer look on how banks in Indonesia practices risk management. Specifically we focus on practices between pre and post IDIC establishment. Although there are various risks inherent in banking operations but here we investigate 3 major types namely credit risk, market risk and operation risk ${ }^{2}$. Initially we aim to reveal market risk that stems from foreign exchange and interest rate movement. Nevertheless we find the data to be non-supportive for observation in foreign exchange risk taking. Around 58 banks (48\% of the sample) are classified as Non Foreign Exchange Banks and Regional Banks. In these types of banks, foreign exchange business is either trivial or nonexistent. Therefore we are focusing more on appropriate class of market risk, that is interest rate risk but still maintaining the notion (that is market risk and interest rate risk are used interchangeably).

We establish empirical scheme in testing relationship between these measures of risk with various factors (shareholders drive, competition, firm size, capital, charter value and macroeconomic condition). The aims of this paper first are to identify factors influencing bank risk taking behavior (credit, market and operational risk), second to reveal the pattern of relationship and possible changes related to establishment of IDIC. Further more we attempt to uncover various form of relationship according to types ( $\mathrm{Bl}$ categories), and third to elicit practical and policy implications based on study results.

The next section present a brief account on IDIC as one of key turning points in Indonesian banking and also present the recent theories and empirical works in risk management. The third section discusses the methodology and the data, including the robustness check of the model, while the fourth section presents the result and analysis. Conclusion and policy implicationis presented on the last section.

\section{THEORY}

\subsection{Indonesia Deposit Insurance Corporation}

Deposits insurance is introduced mostly to evade the disastrous effect of bank panics (Freixas and Rochet, 2008). The scheme gives guarantee to public that deposits could still be withdrawn in the event of bank failure. In an explicit insurance scheme, a premium is usually paid and there are several requirements for deposits withdrawal ${ }^{3}$. The scheme could be run by either a private company, semipublic or government agency. In an implicit insurance, the public sees the scheme as automatic and as a part of procedure to recover confidence to banking system.

The first Deposit Insurance was created in United States as a response to Great Depression. Today, according to International Association of Deposits Insurance (IADI) there are 95 countries

2 See Apostolik et al (2009) and Saunders and Cornett (2003) for an excellent text book on various risk inherent in financial firms and banks.

3 This could be in form of maximum withdrawal, characteristic of coverage (types of product, maximum interest rate, nominal amount, etc) and procedure. 
that have deposits insurance (explicit or implicit). This is more than $60 \%$ of existing countries. There are various features of deposits insurance from coverage, characteristics of risk premium, existence of co-insurance and funding. Kunt et al (2005) studied and documented these features (see table 1).

Most deposits insurance corporations (DIC) are jointly funded (63\%). Around 36\% are privately capitalized and only $1 \%$ that is pure public funded. Interestingly even though most DIC's are jointly financed, most of them are administered by the state (60\%). Around $27 \%$ are jointly operated and only $12 \%$ are pure private administration. It seems that government presence intervention is still desired.

\begin{tabular}{|c|c|c|c|}
\hline \multicolumn{4}{|c|}{$\begin{array}{c}\text { Table } 1 . \\
\text { Features of Deposits Insurance }\end{array}$} \\
\hline No & Feature & No of Countries & Proportion \\
\hline 1 & Foreign Currency Deposit Covered & 61 & 76 \\
\hline 2 & Interbank Deposit Covered & 14 & 18 \\
\hline 3 & Co Insurance Exist & 21 & 25 \\
\hline 4 & Payment per Depositor & 66 & 79 \\
\hline 5 & Scheme is permanently funded & 69 & 84 \\
\hline 6 & Premiums are risk adjusted & 20 & 25 \\
\hline 7 & Membership is compulsory & 74 & 91 \\
\hline 8 & Source of Funding & & \\
\hline \multirow{7}{*}{9} & Private & 28 & 36 \\
\hline & Joint & 49 & 63 \\
\hline & Public & 1 & 1 \\
\hline & Administration & & \\
\hline & Official & 49 & 60 \\
\hline & Joint & 22 & 27 \\
\hline & Private & 10 & 12 \\
\hline
\end{tabular}

In a theoretical work, Diamond and Dybvig (1983) showed that Deposits Insurance could provide a solution to bank runs or bank panics. Nevertheless its implementation is not without problem. Freixas and Rochet (2008) elicit three important aspects related to Deposits Insurance. They are (1) moral hazard Issue; (2) risk based pricing and (3) incomplete information problems.

Moral hazard problem arise from weakening incentive of depositors to monitor the banks and increasing risk taking behavior of the manager and shareholder. Deposits insurance works as a put option in part of depositors, and a call option in the view of shareholders. The problems are especially important if the risk premium is not fairly priced: flat or inadequate risk adjusted premium (Greenbaum and Thakor, 2007).

Merton (1977) considers deposits insurance as identical to put option of bank assets at strike price of amount of deposits. He postulates that actuarially fair rate of deposits insurance is an increasing function of deposits to asset ratio and volatility of bank assets. This important 
work has been expanded to various ways; two important works are Pennachi (1987) which includes resolution of bank failure and Acharya and Dreyfus (1988) which considers possibility of authority takes over the bank before it is really insolvent.

Chan et al (1997) shows that within incomplete information environment, the fairly priced deposit insurance may not be feasible. This is mainly due to (1) timing problems of lag in policy implementation and (2) adverse selection: private market for insurance premium is ceased to exist.

Exposition above shows that the impact of Deposits Insurance to bank behavior might not be so clear. Flat rate might induce more risk taking behavior, however the impact to equilibrium level of deposits and loans margin might diverge (Suarez, 1993). Gennote and Pyle (1991) show that bank might underinvest in loan when bank capital is raised. More recent study by Matutes and Vives (2000) shows that competition might become fiercer with the introduction of deposit insurance, and lead to higher probability of failure.

\subsection{A Review on Risk Taking Behavior}

There are many risk types to consider in bank management. However under spirit of Basel II, generic classes of bank risk could be categorized as credit, market and operational risk. Credit risk could be defined as probabilities that one or more component of bank portfolio experience a default (Freixas and Rochet, 2008). Credit risk could be further classified into individual risk and portfolio risk (Saunders and Cornett, 2003). Individual risk could be measured by standard credit analysis procedure famous as 5C jargon: Capital, Condition, Capacity, Collateral and Character (Apostolik et al, 2009). On the other hand portfolio risk mainly rises from degree of concentration and correlation (lack of diversification).

Theoretically a loan could be depicted as a complete contingent contract that specify in every state of nature and interim date of the following conditions (Freixas and Rochet, 2008):
a. The amount of repayment
b. The interest rate on the remaining debt
c. A possible adjustment in the collateral required by the lender
d. The actions to be undertaken by the borrower

The basic model of lender-borrower first developed by Wilson (1968) hinges on symmetric information assumption. Under this assumption, the sensitivity of repayment rate as a function of firm operation is high when the borrower is more risk averse than the lender (and vice versa). This model has been improved in two important ways.

One development is the work of Townend (1979) and Gale and Hellwig (1985) in which they relaxed the assumption into asymmetric information. Lender bears significant cost to 
reveal the exact nature of borrower business (called state verification). Under this more realistic assumption, lenders should develop incentive compatible contracts. There could be many contracts that have this property thus the next task for the lender is to pick up the most efficient one. An efficient incentive compatible contract is obtained by maximizing the probability of an audit for a fixed expected repayment amount or maximizing expected repayment for a fixed probability of an audit. If both agents are risk neutral, any efficient incentive compatible debt contract is a standard debt contract.

The other is introducing a possibility of moral hazard after the loan is granted. Innes (1990) is the most cited work in the area. Assuming the limited liability of the borrower and individual rationality constraints, a model is developed to shape the optimal repayment function. The model also assume the monotone likelihood ratio property (Holmstrom, 1979), in which business result is an appropriate signal of effort. It is shown that the correct incentive compatible repayment scheme is function of effort. The borrower is imposed penalty if the observed result is lower than a particular threshold (obtained via solution to lender return maximizing problem). The borrower is given reward in form of zero additional repayment if his effort exceeds the threshold.

There are several other variants and combination works from these two major strains. Bolton and Scharfstein (1990) construct a model in which borrower's investment is not verifiable. Jappeli et al (2005) propose a model in which borrower could dispute the lender's claim in court. Hart and Moore (1994) stress an important fact that the contract cannot impose on the borrower any restriction on the freedom of walk away. Myers and Rajan offer a model under condition of possible asset substitution opportunities. These models show that different result could be obtained in the lender-borrower relationship.

Pyle (1971) and Hart and Jaffe (1974) are the first theoretical works that give birth to market risk meaning. They view bank as a portfolio manager which obtained funds in various form and tenor then invest them into assets. They regard loans which are inherently non tradable as tradable securities. These securities are valued using a risk free rate asdiscount factor.

At a point of time, bank could be in an open position. They have mismatches in deposits versus loan characteristics (especially in tenor and currency denomination). With regard to interest rate, Hart and Jaffe (1974) show that as long as risk free interest rate remains between deposits and lending rate then bank has position in loan (securities) and deposits are positive.

Practically market risk could be measure as return variability of a trading portfolio (Saunders and Cornett, 2003). This variability could result from changes in interest rate and exchange rate. There are three types of calculating market risk that commonly used: Risk Metrics ${ }^{4}$, historic simulation and Monte Carlo.

4 This instrument was first introduced by JP Morgan, see www.jpmorganchase.com for technical documents. Risk metrics was further developed and currently famous as Value at Risk. In a nutshell, this concept describe what is the extent of the loses if the day turn out to be a bad day. 
Basel committee (2001) defined operational risk as potential loss (both direct and indirect) due to failure or inadequate internal system. This class of risk includes among other system failure, reputational risk, fraud and strategic risk.

Jeitschko and Jeung (2005) develop an interesting theoretical work on aggregate risk positioning by banks which depends on various conditions. There are two critical aspects in their theorem: (1) strategic interaction among three important parties: deposit insurance, shareholder and manager and (2) four types risk profile which are more realistic than strict mean variance ordering that usually assumed in typical studies ${ }^{5}$.

They show that with mean-variance ordering profile: high risk high return, three important parties in banking industry would have positive preference for risky assets. Shareholders are the highest, followed by management and deposit insurance respectively.

Saunders et al (1990) investigate empirically the relationship of ownership and bank risk taking. Using a panel dataset consist of 38 US banks at annual frequency during 1978-1985 period, they tested whether stockholder controlled banks have greater incentives to take risk than managerially controlled bank. They experiment with seven capital market risk sensitivity measures (derived by Capital Asset Pricing Model).In their study they find evidence in support of the hypotheses: stockholder controlled banks exhibit significantly higher risk taking behavior than managerially controlled.

Risk taking incentive may change before commencement of a business plan (ex ante) and after (ex-post). This possibilityis studied by Galloway et al (1997) using database of 86 US banks, at daily frequency during 1977-1994 periods. They use a market based risk measure, annual standard deviation of weekly equity return and several explanation variables (charter value, market to book value, capital, and operating leverage among others). They find that charter value correlates negatively with risk taking measures.

A more recent study conducted by Marco and Fernandez (2007) on relationship of risk taking behavior on ownership structure and size of entities. They use two risk proxies: risk of failure (a Z score) and level of exposure to insolvency (inspired by Value at Risk paradigm). The data are an unbalanced panel consists of 256 Commercial and Savings banks in Spain from 1993 to 2000 at annual frequency (total 1030 observations). Using control variables like return on equity, lending to asset ratio and dummy of size and dynamic panel data econometrics they find evidence that risk proxies are inversely related to size. They also find that commercial banks are more risk inclined than the Savings banks.

Our approach in this study is different in several way from previous works outlined above. First we are comprehensive. We include almost all commercial banks operational in Indonesia in post crisis era. Second, we use simple (accounting) risk measures against common set explanatory

5 Mean and variance are characteristics of distribution (also known as the first and second moments). Like a scalar, distribution could also be compared using concept of stochastic dominance. For an introduction to this topic, please see Davidson (2006). 
variables to verify the relationship hypotheses. Third we take account on the impact of IDIC implementation on risk taking behavior. Last, we also view possibilities of interactions among different types of banks (using BI categories).

\section{METHODOLOGY}

This study aims to reveal the risk taking behavior of the bank (credit, market and operational risk) against common set of independent variables (bank characteristics, competition and macro economy). We use panel dataset from published financial report. Dataset comprises of commercial banks operating during 2000 to 2009 (121 banks) with semiannual frequency. There are 2420 observations in the dataset ${ }^{6}$.

A linear model was used as empirical scheme to test relationships between risk taking and independent variables. Mathematically it could be expressed in the following form

$$
S_{i t}=\alpha_{0}+\alpha_{i} X_{i}+\varepsilon_{i t}
$$

where $S_{i t}$ is a vector of risk taking variables (credit, market and operational) and Xis vector of independent variables. The scheme comprises of 3 risk taking variables and 11 independent variables. Definitions, proxies of variables and expected sign of hypotheses are given in Table 1 below.

\begin{tabular}{|c|c|c|c|}
\hline \multicolumn{4}{|c|}{$\begin{array}{c}\text { Table } 2 . \\
\text { Definition and Operational Term of Variables }\end{array}$} \\
\hline No. & Variables & Description, Proxy and Notation & Expected Sign \\
\hline \multicolumn{4}{|c|}{ Risk Variables } \\
\hline 1 & Credit Risk & $\begin{array}{l}\text { Bank exposure to credit risk which is proxied by ratio } \\
\text { for Non-Performing Assets to Bad Debt Allowance (in } \\
\text { percentage). Notation: CR. }\end{array}$ & Dependent Variable \\
\hline 2 & Interest Rate Risk & $\begin{array}{l}\text { Bank's exposure to market risk (especially interest rate) } \\
\text { which is proxied by ratio of Loan To Deposit Ratio (in } \\
\text { percentage): MR }\end{array}$ & Dependent Variable \\
\hline 3 & Operational Risk & $\begin{array}{l}\text { Bank's exposure to operational risk which is proxied } \\
\text { by operational leverage: ratio of fixed asset to total } \\
\text { asset. Notation (in percentage):OR }\end{array}$ & Dependent Variable \\
\hline \multicolumn{4}{|c|}{ Internal Characteristics } \\
\hline 1 & Shareholders influence & $\begin{array}{l}\text { Profitability target required by shareholders which is } \\
\text { proxied by ratio return to equity (in percentage). Notation: } \\
\text { ROE }\end{array}$ & Positive \\
\hline 2 & $\begin{array}{l}\text { Human Resource } \\
\text { Productivity }\end{array}$ & $\begin{array}{l}\text { Personal motivation and drive stimulated by banks } \\
\text { which is proxied by ratio of personnel related expense } \\
\text { to total operational cost (in percentage). Notation: HRP }\end{array}$ & $\begin{array}{l}\text { Positive(CR and MR), } \\
\text { Negative(OR) }\end{array}$ \\
\hline
\end{tabular}

6 Risks measures are missing or unavailable in several banks especially in early period. Therefore actually we work on unbalanced panel data. The degree of severity of imbalance is different among regressions (credit, market and operational risk). 


\begin{tabular}{|c|c|c|c|}
\hline 3 & Bank Size* & $\begin{array}{l}\text { Size and scale of production of the bank which is } \\
\text { proxied by value of total asset (in million Rupiah). } \\
\text { Notation: SIZE. }\end{array}$ & $\begin{array}{l}\text { Negative (Saunders et } \\
\text { al, 1997) }\end{array}$ \\
\hline 4 & Capital & $\begin{array}{l}\text { Capital owned by banks which is proxied by equity } \\
\text { multiplier: ratio equity to total assets (in percentage). } \\
\text { Notation: CAP }\end{array}$ & $\begin{array}{l}\text { Positive (Jeitschko and } \\
\text { Jeung, 2005) } \\
\text { orNegative (Keeley and } \\
\text { Furlong, 1990) }\end{array}$ \\
\hline 5 & Charter Value & $\begin{array}{l}\text { Future value of banks from the view of prospective } \\
\text { investors which is proxied by ratio of total equity to paid } \\
\text { in capital. Notation: FV }\end{array}$ & $\begin{array}{l}\text { Negative (Marcus, } \\
\text { 1984) }\end{array}$ \\
\hline 6 & Product Diversification & $\begin{array}{l}\text { Managerial orientation: traditional (intermediation) } \\
\text { versus modern (supermarket of financial services) } \\
\text { which is proxied Total Asset To Loan. Notation: DIVER }\end{array}$ & Any \\
\hline \multicolumn{4}{|c|}{ Industry Characteristics Variables } \\
\hline 7 & Competition* & $\begin{array}{l}\text { Competition intensity of banking industry which is } \\
\text { proxied by Herfindahl Hirschman Index (calculated from } \\
\text { total assets). Notation: COMP }\end{array}$ & $\begin{array}{l}\text { Positive (Keeley) or } \\
\text { Negative (Boyd and De } \\
\text { Nicolo, 2005) }\end{array}$ \\
\hline 8 & Liquidity & $\begin{array}{l}\text { Provision of liquid assets in the industry which is proxied } \\
\text { by Banking System ratio of Loan to total Deposit. } \\
\text { Notation: LIQ }\end{array}$ & $\begin{array}{l}\text { Positive (Prisman et al, } \\
\text { 1986) }\end{array}$ \\
\hline \multicolumn{4}{|c|}{ Macro Economy Variables } \\
\hline 9 & $\begin{array}{l}\text { Economics and Business } \\
\text { Prospect }\end{array}$ & $\begin{array}{l}\text { General condition of economy which is proxied by GDP } \\
\text { Growth (percentage point, yoy). Notation: GRW }\end{array}$ & Positive \\
\hline 10 & Inflation Rate & $\begin{array}{l}\text { Rate of change of general price which is proxied by } \\
\text { consumer price index percentage change (YoY). } \\
\text { Notation: INF. }\end{array}$ & $\begin{array}{l}\text { Positive (Prisman et al, } \\
\text { 1986) }\end{array}$ \\
\hline 11 & $\begin{array}{l}\text { Pressure on Balance of } \\
\text { Payment }\end{array}$ & $\begin{array}{l}\text { General condition on foreign capital flow which is proxied } \\
\text { by annual currency depreciation/appreciation rate (in } \\
\text { percentage). Notation: EXT. }\end{array}$ & Negative \\
\hline
\end{tabular}

Examination of pre and post IDIC establishment risk behavior is conducted using dummy event variables (notation: IDIC). These categorical variables are used both to signify level effect and behavior shift (interaction term with independent variables). The behavioral shift is assumed only occur to internal characteristics variables. If this regulatory institution works effectively we could expect that all variables are smaller in absolute size (i.e. the dummy event variables would take an opposite numerical value).

The empirical scheme will also explore the possible effect on greater detail. Here we will direct our focus on different impact due to types. We use Bank Indonesia (Central Bank) categories and generate dummy variable called TYPE. The categories are State Owned Enterprise (SOE) Banks, Regional Development Bank, Private Foreign Exchange Bank, Private Non Foreign Exchange Bank and Foreign Owned-Joint Venture Bank. The notations are 1, 2, 3, 4 and 5 respectively. Again we look for possible interaction effect from IDIC implementation and bank types. 
We use 3 econometric techniques to obtain the estimates ${ }^{7}$. They are Panel Estimated Generalized Least Squares (EGLS), Fixed Effect (FE) and Random Effect (RE). Apriory we don't know the exact pattern of error component. They could be pooled residual, fixed or random between observations. Here we only take assumption of possible difference between cross section units not period. This is one way error component that can be either fixed or random. Error type could also not include into these classifications, therefore we still maintain pooled estimation with heteroscedasticity robust property (EGLS).

\section{RESULTS AND ANALYSIS}

This section presents estimation results on various econometrics specification and notes on their robustness (diagnostic test). First we would convey the regression result applied to all data (without including the effect of IDIC implementation). In the next sub section, we will present the impact of IDIC implementation. First we will see its general impact and then explore in greater detail i.e. affect by bank types.

\subsection{Overall Behavior Result}

Table 3 shows the result of all sample credit risk taking regression. Credit risk as proxied by ratio of non performing loan to allowance is regressed to various explanation variables. Here we have results that some what different with previous studies.

\begin{tabular}{|c|c|c|c|c|}
\hline \multicolumn{5}{|c|}{$\begin{array}{l}\text { Table } 3 . \\
\text { Estimation Result on Credit Risk (all period) }\end{array}$} \\
\hline \multirow{2}{*}{ No. } & \multirow{2}{*}{$\begin{array}{c}\text { Dep Vat: CR } \\
\text { Variables/Proxies }\end{array}$} & \multicolumn{3}{|c|}{ Estimates* } \\
\hline & & EGLS & FE & RE \\
\hline 1 & C & $322.95(0.00)$ & $532.62(0.00)$ & $179.68(0.38)$ \\
\hline 2 & ROE & $-0.020(0.09)$ & $-0.044(0.11)$ & $-0.170(0.05)$ \\
\hline 3 & HRP & $-1.024(0.00)$ & $-0.941(0.00)$ & $-1.104(0.24)$ \\
\hline 4 & SIZE & $-9.729(0.00)$ & $-23.74(0.00)$ & $-33.74(0.01)$ \\
\hline 5 & CAP & $-0.001(0.00)$ & $0.001(0.28)$ & $-0.004(0.00)$ \\
\hline 6 & CV & $0.110(0.03)$ & $0.112(0.07)$ & $0.044(0.53)$ \\
\hline 7 & DIVER & $-1.834(0.15)$ & $1.224(0.39)$ & $16.39(0.15)$ \\
\hline 8 & COMP & $-0.105(0.00)$ & $-0.069(0.01)$ & $0.199(0.01)$ \\
\hline 9 & LIQ & $0.548(0.15)$ & $1.024(0.01)$ & $5.309(0.00)$ \\
\hline 10 & GROWTH & $-1.664(0.02)$ & $-2.193(0.01)$ & $2.879(0.28)$ \\
\hline 11 & INF & $-0.644(0.13)$ & $-0.649(0.05)$ & $-0.760(0.45)$ \\
\hline 12 & EXT & $0.119(0.01)$ & $0.018(0.76)$ & $0.237(0.51)$ \\
\hline \multicolumn{5}{|c|}{ Goodness of Fit } \\
\hline & $\mathrm{R} 2$ & 0.657 & 0.707 & 0.120 \\
\hline & Adjusted R2 & 0.654 & 0.687 & 0.115 \\
\hline & F Stat & 320.43 & 36.02 & 26.40 \\
\hline
\end{tabular}

7 There are many variants of panel data estimators. We use somewhat standard techniques that are quite popular in usage. Further exposition on this topic could be obtained from Baltagi (2005) and Cameron and Triverdi (2008). 
First aligned with Saunders et al (1997), we find (credit) risk taking to be negatively affected by bank size. Larger banks tend to be more conservative. The coefficients are the largest among other estimators, ranging from -9.3 (EGLS) to -33.74 (RE). Since these are semi elasticities, $1 \%$ increased of size (ceteris paribus) would decrease credit risk taking position $9.3 \%$ to $33.74 \%$. We also find competition to be negatively influence (credit) risk taking behavior (EGLS and FE) as suggested by Boyd and De Nicolo (2005). Last we also find Capital to be in line with existing literature since it could go both ways. Our findings then are closer to those of Keeley and Furlong (1990).

Contrary to previous studies and intuition, we find that variables of ROE, personnel cost ratio (HRP), and Growth as non-increasing with risk. Contrary to theoretical result of Jeitschko and Jeung (2005), higher value of ROE does not seem to correlate with aggressive risk taking. We think large portion of government bonds and left over effect of 1997 great crisis has tempered management risk appetite while at the same time provide decent return. Indonesian banking industry is dominated by large banks (with share more than 70\%) that are recapitalized after the crisis. These would affect the estimation result. The same argument could be said to explain the result of HRP and Growth.

\begin{tabular}{|c|c|c|c|c|}
\hline \multicolumn{5}{|c|}{$\begin{array}{l}\text { Table } 4 . \\
\text { Estimation Result on Interest Rate Risk: all period }\end{array}$} \\
\hline \multirow{2}{*}{ No. } & \multirow{2}{*}{$\begin{array}{c}\text { Dep Vat: MR } \\
\text { Variables/Proxies }\end{array}$} & \multicolumn{3}{|c|}{ Estimators* } \\
\hline & & EGLS & $\mathrm{FE}$ & RE \\
\hline 1 & C & $87.758(0.00)$ & $455.46(0.00)$ & $163.38(0,11)$ \\
\hline 2 & ROE & $-0.110(0.00)$ & $0.006(0.63)$ & $-0.403(0,34)$ \\
\hline 3 & HRP & $-0.490(0.00)$ & $0.311(0.00)$ & $-0.093(0,78)$ \\
\hline 4 & SIZE & $-1.092(0.00)$ & $-31.71(0.00)$ & $-8.271(0,21)$ \\
\hline 5 & CAP & $1.890(0.00)$ & $-0.0009(0.00)$ & $-0.0002(0,33)$ \\
\hline 6 & $\mathrm{FV}$ & $0.055(0.00)$ & $0.002(0.82)$ & $0.061(0,34)$ \\
\hline 7 & DIVER & $-1.556(0.00)$ & $-0.320(0.00)$ & $-0.903(0.04)$ \\
\hline 8 & COMP & $-0.012(0.33)$ & $0.024(0.05)$ & $0.040(0.23)$ \\
\hline 9 & LIQ & $0.156(0.30)$ & $1.302(0.00)$ & $0.793(0.00)$ \\
\hline 10 & GROWTH & $-0.562(0.28)$ & $-0.084(0.84)$ & $-6.573(0.26)$ \\
\hline 11 & INF & $-0.123(0.49)$ & $-0.170(0.31)$ & $1.194(0.27)$ \\
\hline 12 & EXT & $0.072(0.24)$ & $-0.036(0.33$ & $-0.444(0.32)$ \\
\hline \multicolumn{5}{|c|}{ Goodness of Fit } \\
\hline & $\mathrm{R} 2$ & 0.365 & 0.870 & 0.019 \\
\hline & Adjusted R2 & 0.361 & 0.861 & 0.014 \\
\hline & F Stat & 104.50 & 108.74 & 4.063 \\
\hline
\end{tabular}

Here we also find the strongest impact of the bank size to theirrisk taking behavior (see Table 4). The magnitude of the coefficients is ranged from -1.09 to -31.71 (the largest of all 
estimates). An increase in $1 \%$ of bank size, on average would reduce the loan to deposit ratio by $1.09 \%$ to $31.7 \%$. For this market risk type, the role of capital is closer to the one proposed by Jeitschko and Jeung (2005). More capital would likely to induce greater interest rate exposure (through higher LDR). With regards to competition, our findings are closer to that of Keeley (1990). More competition would induce aggressive (interest rate) risk taking.

We find non supportive (and mixed) evidence regarding the role of ROE, HRP and growth to interest rate risk taking. ROE and HRP have a small albeit negative effect to LDR while growth estimates are not significant in all techniques used. Again we suggest the left over impact of crisis and recapitalization program should help explain this occurrence.

One interesting additional findings are on DIVER variables. DIVER that measures the extent banks operate beyond their traditional intermediation role prove to be risk reducing. It seems that diversification activities taken by banks are detached to intermediation function. Indeed casual observation shows that in last decade other business unrelated to traditional role is flourishing. These activities include among others bank assurance, electronic-internet banking, wealth management, etc. The business mostly is fee based.

\begin{tabular}{|c|c|c|c|c|}
\hline \multicolumn{5}{|c|}{$\begin{array}{l}\text { Table } 5 . \\
\text { Estimation Result on Operational Risk: (all period) }\end{array}$} \\
\hline \multirow{2}{*}{ No. } & \multirow{2}{*}{$\begin{array}{c}\text { Dep Var: OR } \\
\text { Variables/Proxies }\end{array}$} & \multicolumn{3}{|c|}{ Estimators* } \\
\hline & & EGLS & $\mathrm{FE}$ & RE \\
\hline 1 & C & $46.77(0.00)$ & $34.278(0.00)$ & $26.837(0.00)$ \\
\hline 2 & ROE & $-0.0007(0.09)$ & $-0.0005(0.17)$ & $-0.005(0.00)$ \\
\hline 3 & HRP & $0.003(0.38)$ & $0.003(0.46)$ & $0.013(0.23)$ \\
\hline 4 & SIZE & $-2.271(0.00)$ & $-2.287(0.00)$ & $-1.71(0.00)$ \\
\hline 5 & CAP & $0.0001(0.00)$ & $0.0001(0.00)$ & 7.62E-05 $(0.00)$ \\
\hline 6 & $\mathrm{FV}$ & $0.0003(0.29)$ & $0.0003(0.19)$ & $0.0007(0.00)$ \\
\hline 7 & DIVER & $-0.002(0.04)$ & $-0.002(0.09)$ & $-0.010(0.01)$ \\
\hline 8 & COMP & $0.0005(0.02)$ & $0.0007(0.06)$ & $9.58 \mathrm{E}-06(0.98)$ \\
\hline 9 & LIQ & $0.006(0.31)$ & $0.045(0.00)$ & $0.034(0.00)$ \\
\hline 10 & GROWTH & $0.002(0.80)$ & $-0.0092(0.34)$ & $-0.033(0.15)$ \\
\hline 11 & INF & $-0.001(0.59)$ & $-0.017(0.00)$ & $-0.024(0.00)$ \\
\hline 12 & EXT & $0.001(0.12)$ & $0.0001(0.93)$ & $-0.0007(0.74)$ \\
\hline \multicolumn{5}{|c|}{ Goodness of Fit } \\
\hline & $\mathrm{R} 2$ & 0.945 & 0.953 & 0.230 \\
\hline & Adjusted R2 & 0.945 & 0.950 & 0.226 \\
\hline & F Stat & 3118.3 & 332.43 & 59.47 \\
\hline
\end{tabular}

Last, the evidences from operational risk are also in line with Saunders et al (1997). Here larger banks are associated with less operational risk taking. The magnitude is considerable 
convergent and lower than the other two risk types. $1 \%$ increase in size (ceteris paribus) would reduce ratio of fixed asset to total asset by $1.71 \%$ to $2.29 \%$. The role of capital and competition is small although significant and in line with Jeitschko and Jeung (2005) and Keleey (1990).

In addition to estimating parameters, we also perform testing on choosing the appropriate model $^{8}$. First we conduct Redundant Fixed Effect test (Log likelihood ratio) to test whether the Fixed Effect model (FEM) is suitable. The results strongly conforms the use of this model. The null hypotheses of (jointly) zero fixed cross section effect are strongly rejected. The F statistics are 3.58, 3.05 and 4.41 for credit, interest rate and operational risk respectively. Next, we take the analog test for random effect specification (The Hausman Test). Here the null hypotheses of (jointly) no random effect could not be rejected statistically. Taken together both specification tests would conclude that Fixed Effect Model is more superior in estimating the relationship of risk taking behavior to various factors. Based on this result, we decide to use FE technique in further exploration.

\subsection{The Impact of IDIC Overall Bank Result}

Overall regressions show that implementation of IDIC alters the risk taking behavior of banks (see table 6). First we review the credit risk taking behavior. The constant term is increased by 93 points. It would suggest inherently, banks are more aggressive in taking exposure in credit.

\begin{tabular}{|c|c|c|c|c|}
\hline \multicolumn{5}{|c|}{$\begin{array}{l}\text { Table } 6 . \\
\text { The Impact of IDIC implementation (Overall result) }\end{array}$} \\
\hline No. & Variables/proxies & $\mathrm{CR}^{*}$ & $M^{*}$ & $\mathrm{OR}^{*}$ \\
\hline 1 & C & $403.12(0.00)$ & $371.82(0.00)$ & $29.429(0.00)$ \\
\hline 2 & ROE & $-0.112(0.02)$ & $0.004(0.82)$ & $-0.0001(0.70)$ \\
\hline 3 & HRP & $-0.503(0.06)$ & $0.065(0.43)$ & $0.004(0.06)$ \\
\hline 4 & SIZE & $-22.15(0.00)$ & $-26.285(0.00)$ & $-1.966(0.00)$ \\
\hline 5 & CAP & $0.269(0.42)$ & $0.747(0.00)$ & $0.001(0.65)$ \\
\hline 6 & CV & $0.028(0.64)$ & $-0.010(0.68)$ & $0.0008(0.04)$ \\
\hline 7 & IDIC & $93.268(0.00)$ & $-8.543(0.37)$ & $-0.852(0.01)$ \\
\hline 8 & IDIC*ROE & $0.016(0.82)$ & $-0.009(0.65)$ & $-0.0006(0.20)$ \\
\hline 9 & IDIC*HRP & $-1.194(0.00)$ & $0.455(0.00)$ & $0.0009(0.77)$ \\
\hline 10 & IDIC*SIZE & $-4.565(0.00)$ & $0.057(0.92)$ & $0.062(0.00)$ \\
\hline 11 & IDIC*CAP & $2.100(0.00)$ & $-0.748(0.00)$ & $-0.001(0.69)$ \\
\hline 12 & IDIC*CV & $0.135(0.02)$ & $0.006(0.82)$ & $-0.0006(0.15)$ \\
\hline \multicolumn{5}{|c|}{ Goodness of Fit } \\
\hline 13 & $\mathrm{R} 2$ & 0.615 & 0.872 & 0.948 \\
\hline 14 & Adjusted R2 & 0.588 & 0.863 & 0.944 \\
\hline 15 & F Stat & 22.69 & 105.47 & 281.39 \\
\hline \multicolumn{5}{|c|}{${ }^{*}$ Coefficient value, $p$ value in parentheses } \\
\hline
\end{tabular}

8 We do not present the statistic calculation in this article. Interest reader could contact the author for the result. 
This evidence contradicts the maintain hypotheses that implementation of IDIC would reduce risk taking drive. We can use the low loan exposures during the first half of the decade to explain this anomaly. After recapitalization, banks are usually reluctant to extend the credit since it might deteriorate their capital position that has just beingrecovered.

However things might change once the IDIC was implemented in 2005. Coupled with low realization, the implementation could be seen as a boost to lending activities. As Suarez (1993) first put it, the deposit insurance work to reduce the cost of deposit, the most important input to lending and in the same time increase the value of loan to banks. Both can increase the risk exposure of loan, which is proxied with the ratio of non-performing loan to bad debt allowance.

Further evidence on this hypotheses is given by positive and significant of IDIC ${ }^{*}$ CAP interaction term. A one percent increase in capital would result in 2.1 percent more credit risk exposure post IDIC implementation. The credit risk taking behavior increases as the banks have higher charter value (this is contrast to the work of Marchus, 1984).

On the other hand, the implementation of IDIC does not have a direct effect on the interest rate risk taking behavior. The estimated coefficient of IDIC, which should alter the constant, is not significant though the sign is negative as expected. However, the implementation of the IDC has an indirect affect through personnel incentive (HRP) and the capital (CAP). A one percent increase of personnel incentive will increase the interest rate risk taking behavior of 0.455 , while the capital works in the opposite effect of -0.748 (See column 4 on Table 6).

Operational risk is the only measure that in line with hypotheses. The impact of IDIC implementation is negative and significant (-0.852). Nevertheless most explanatory variables are either very small or statistically insignificant.

Aligned with above findings, banks size is negatively correlated with risk taking position. Nevertheless related to IDIC implementation, the impacts are diverged. Larger banks are becoming even more reluctant to extend their credit risk position than the smaller ones after IDIC event. One percent increase in size would result in 4.56 percent reductionin credit risk compared to pre IDIC implementation. The interaction of IDIC and the size impacts are either not significant and/or very small for interest rate risk and operational risk.

\section{Controlling the Bank's Type}

The responseson IDIC implementation differ markedly across types of banks. We use the State Owned (SOE) Banks as baseline category. To have the net effect of each category, we subtract the baseline coefficient to interaction term ${ }^{9}$. The algebraic sign is sufficient to show when

9 For example the net impact of size to credit risk taking for Private Foreign Exchange Bank Category is 11.871 that is obtained from $-45.862+57.733$. 
particular type of bank behavesmore conservative or more aggressive relative to our benchmark banks (SOE banks).

Table 7 present the estimation result for the risk taking behavior using the credit risk proxy. ROE and SIZE are two variables that make the SOE banks to behave more conservative after the implementation of IDIC. We address the explanation of ROE impacton SOE banks to the benefit of recapitalization program as previously stated. Nevertheless the positive sign on Private Foreign Exchange bank and Foreign-Joint Venture category indicates the managerial drives to a more aggressive risk taking behavior, which is widely observed in practice.

As explained earlier from Table 6, larger SOE banks tend to choose less risk. Surprisingly, the other types of bank move on the opposite. The Regional and the Private Foreign Exchange Bank respond differently when their size increases. For every 1 percent increase in size after the IDIC implementation, both will increase their exposure on credit risk in the magnitude (net effect) of 5.427 and 11.871 respectively.

\begin{tabular}{|c|c|c|c|c|c|}
\hline \multicolumn{6}{|c|}{$\begin{array}{l}\text { Table } 7 . \\
\text { The Impact of IDIC implementation: Credit Risk (across Bank Types) }\end{array}$} \\
\hline \multirow{2}{*}{ Type } & \multicolumn{5}{|c|}{ Interaction Terms } \\
\hline & ROE & HRP & SIZE & CAP & CV \\
\hline \multirow[t]{2}{*}{ State Owned Bank $(\text { Type }=1)^{*}$} & -2.236 & -1.796 & -45.862 & 13.730 & 12.476 \\
\hline & $(0.05)$ & $(0.18)$ & $(0.04)$ & $(0.02)$ & $(0.42)$ \\
\hline \multirow[t]{2}{*}{ Regional Bank (Type $=2)^{\star *}$} & 1.484 & 1.797 & 51.289 & -11.486 & -10.002 \\
\hline & $(0.20)$ & $(0.20)$ & $(0.02)$ & $(0.04)$ & $(0.55)$ \\
\hline \multirow{2}{*}{$\begin{array}{l}\text { Private Foreign Exchange } \\
(\text { Type }=3)^{\star *}\end{array}$} & 2.374 & 1.159 & 57.733 & -12.134 & -22.034 \\
\hline & $(0.03)$ & $(0.45)$ & $(0.01)$ & $(0.03)$ & $(0.16)$ \\
\hline \multirow{2}{*}{$\begin{array}{l}\text { Private Non Foreign Exchange } \\
(\text { Type }=4)^{\star *}\end{array}$} & 0.352 & 1.322 & 27.453 & -13.266 & -16.135 \\
\hline & $(0.78)$ & $(0.42)$ & $(0.25)$ & $(0.02)$ & $(0.31)$ \\
\hline \multirow{2}{*}{$\begin{array}{l}\text { Foreign-Joint venture Bank } \\
(\text { Type }=5 \text {, base category })^{* *}\end{array}$} & 2.117 & 2.119 & 45.283 & -14.124 & -12.330 \\
\hline & $(0.07)$ & $(0.15)$ & $(0.05)$ & $(0.01)$ & (0.43) \\
\hline
\end{tabular}

On the other hand, the increase of capital after the IDIC implementation intensifies the credit risk taking behavior in SOE banks. For every one percent capital increase, the SOE banks increase their credit risk exposure by 13.73 percent, after the implementation of IDIC. Other types of bank response less aggressive or turn out to be aggressive. On average, due to the capital increase, the other bank types are less aggressive by less than a quarter relative to the SOE responses. The response is even negative for Foreign-Joint Venture banks, showing it becomes conservative. Credit risk position response to both HRP and Charter Value does not significantly differ across types of banks. This is in line with the overall regression. 


\begin{tabular}{|c|c|c|c|c|c|}
\hline \multicolumn{6}{|c|}{$\begin{array}{l}\text { Table } 8 . \\
\text { The Impact of IDIC implementation: Interest Rate Risk (across Bank Types) }\end{array}$} \\
\hline \multirow{2}{*}{ Type } & \multicolumn{5}{|c|}{ Interaction Terms } \\
\hline & ROE & HRP & SIZE & CAP & CV \\
\hline \multirow[t]{2}{*}{ State Owned Bank $(\text { Type }=1)^{*}$} & -0.230 & -0.279 & -11.731 & 0.621 & 6.862 \\
\hline & $(0.52)$ & $(0.53)$ & $(0.22)$ & $(0.80)$ & $(0.33)$ \\
\hline \multirow[t]{2}{*}{ Regional Bank $(\text { Type }=2)^{* *}$} & 0.315 & 0.400 & 11.381 & 2.654 & -14.872 \\
\hline & $(0.40)$ & $(0.40)$ & $(0.24)$ & $(0.30)$ & $(0.04)$ \\
\hline \multirow{2}{*}{$\begin{array}{l}\text { Private Foreign Exchange } \\
(\text { Type }=3)^{\star *}\end{array}$} & 0.187 & 0.289 & 11.114 & -0.129 & -5.896 \\
\hline & $(0.60)$ & $(0.56)$ & $(0.25)$ & $(0.96)$ & $(0.40)$ \\
\hline \multirow{2}{*}{$\begin{array}{l}\text { Private Non Foreign Exchange } \\
(\text { Type }=4)^{* *}\end{array}$} & 0.481 & 1.024 & 7.573 & -1.060 & -6.974 \\
\hline & $(0.19)$ & $(0.03)$ & $(0.44)$ & $(0.67)$ & $(0.32)$ \\
\hline \multirow{2}{*}{$\begin{array}{l}\text { Foreign-Joint venture Bank } \\
\text { (Type }=5 \text {, base category) })^{* *}\end{array}$} & -0.158 & 0.254 & 31.184 & -0.821 & -6.757 \\
\hline & $(0.71)$ & $(0.69)$ & $(0.00)$ & $(0.75)$ & (0.33) \\
\hline
\end{tabular}

The next proxy for risk is interest rate and is termed as market risk (See Table 8). There is little evidence that the response of market or interest rate risk differs across banks types. From Table 8, the bank market risk response differs on only two variables; first is HRP influence on Private Non Foreign Exchange Bank and the other is Size on Foreign-Joint Venture banks. After the implementation of IDIC, the HRP increase the market risk exposure in Private Non Foreign Exchange Bank more than the other bank types. The same effect applies for variable Size in Foreign-Joint Venture banks.

\begin{tabular}{|c|c|c|c|c|c|}
\hline \multicolumn{6}{|c|}{$\begin{array}{l}\text { Table } 9 . \\
\text { The Impact of IDIC implementation: Operational Risk (across Bank Types) }\end{array}$} \\
\hline \multirow{2}{*}{ Type } & \multicolumn{5}{|c|}{ Interaction Terms } \\
\hline & ROE & HRP & SIZE & CAP & CV \\
\hline \multirow[t]{2}{*}{ State Owned Bank $(\text { Type }=1)^{*}$} & -0.013 & -0.024 & -0.406 & 0.282 & -0.125 \\
\hline & $(0.30)$ & $(0.09)$ & $(0.10)$ & $(0.00)$ & $(0.48)$ \\
\hline \multirow[t]{2}{*}{ Regional Bank (Type $=2)^{\star \star}$} & 0.010 & 0.018 & 0.450 & -0.257 & 0.092 \\
\hline & $(0.46)$ & $(0.23)$ & $(0.07)$ & $(0.00)$ & $(0.62)$ \\
\hline \multirow{2}{*}{$\begin{array}{l}\text { Private Foreign Exchange } \\
(\text { Type }=3)^{\star *}\end{array}$} & 0.013 & 0.001 & 0.535 & -0.279 & 0.079 \\
\hline & $(0.29)$ & $(0.94)$ & $(0.03)$ & $(0.00)$ & $(0.66)$ \\
\hline \multirow{2}{*}{$\begin{array}{l}\text { Private Non Foreign Exchange } \\
(\text { Type }=4)^{\star *}\end{array}$} & -0.015 & -0.004 & 0.871 & -0.272 & -0.105 \\
\hline & $(0.27)$ & $(0.81)$ & $(0.00)$ & $(0.00)$ & $(0.57)$ \\
\hline \multirow{2}{*}{$\begin{array}{l}\text { Foreign-Joint venture Bank (Type=5, } \\
\text { base category })^{\star *}\end{array}$} & -0.001 & 0.017 & 0.741 & -0.269 & 0.125 \\
\hline & $(0.94)$ & $(0.29)$ & $(0.00)$ & $(0.00)$ & $(0.48)$ \\
\hline
\end{tabular}


Table 9 shows the estimation result for operational risk. We find different response of operational risk between the SOE banks and other bank types. Related to the size of the bank (Size), SOE banks tend to reduce operational risk by 0.406 for every one percentincrease of size after the implementation of IDIC. Contrary to this, the other types of banks raise their operational risk exposure, where the coefficient of interaction term (IDIC * Size) for non-government bank is larger in absolute than the SOE banks. After the implementation of IDIC, as the size of the bank increase, the most conservative positive response belongs to regional banks, while the most aggressive on is private non foreign exchange.

Related to the capital, after the implementation of IDIC the SOE banks tend to increase their operational risk as their capital increase. For every one percent increase in capital, the SOE banks raise their operational risk exposure by 0.282 percent. On the other hand, the other bank types only increase their risk exposure by less than one tenth compared to the SOE response. Their response is quite uniform, where their operational risk position on increase by 0.003 after the implementation of IDIC. The rest of variables: ROE, HRP and CV, do not exhibit different impact across bank types.

\section{Comparison Summary}

Overall view on credit, market and operational risk proxies shows that the SOE banks behave distinctively compared to other bank types. The SOE bankis the most heavily recapitalized one, therefore is closely monitored by various stakeholders ${ }^{10}$. The larger the bank, the more conservative they will be, and it explain the negative correlation between the risk measure and the bank size. For non-government bank the situation is different. Though also were being recapitalized but they have been sold during the period of 2000-2003, hence are "free" from public control. Moreover, the regional bank, the private non foreign exchange and the foreign-joint venture bank are either small or mostly was self-sustained (not recapitalized by government).

Nevertheless due to recapitalization, most SOE banks tended to be too conservative. They are more reluctant to involve in real business activities, there fore they have too low risk exposure. Observing this condition, the public put a pressure on these banks to be more aggressive and to contribute to the business-real sector development ${ }^{11}$. The implementation of IDIC enforces this trend, since it is perceived as implicit guarantee, and is in line with the theory.

The other bank types work on a more sustainable and stable basis. They are free from public pressure and could adhere to their long term business plan without short term discretionary. A particular case is for the foreign-joint venture bank, which become more conservative on taking the credit risk.

10 We should note that in addition to huge economic restructuring, Indonesia is also undergoing a transition to democratic country. Public monitor and participation are rising significantly and various groups in the society are putting high interest on how government spend the money (and also the public corporations performance).

11 Indeed, popular anecdotes are people sees SOE banks management as living on public money. They earn revenue from government bonds that share large portion in the banks book. These bonds many giving coupon that significantly exceed deposits interest rate. 


\section{CONCLUSION}

For Indonesia, the pivotal point in banking regulation is the implementation of Deposit Insurance Corporation (IDIC). The majority of literature both theoretical and empirical suggests that the IDIC event should reduce the incentive to take the risk. The empirical test on this paper provides us several findings. First, most cases show that risk taking behavior is negatively correlated with the size of the bank. Larger bank tends to be more risk averse than the smaller bank. Second, the implementation of IDIC alter the risk taking behavior, but some what different from initial hypothesis. Excluding the interaction terms, the implementation of IDIC tends to raise the credit risk taking. Third, the implementation of IDIC tends to reduce the operational risk taking, which is aligned with the hypotheses. Fourth, the influence of size is significantly less pronounced post IDIC implementation. By controlling the bank types, the result shows that the government bank (SOE) tends to reduce risk as its size increases; and this is the fifth finding. Sixth, the SOE bank also tends to raise risk exposure as its capital increases, while for the other bank types is the opposite.

These findings have several policy implications. First, the IDIC implementation tends to increase the risk taking behavior; and this is a sign of moral hazard as suspected by Freixas and Rochet (2008). The moral hazard in this situation most likely is due to the flat rate insurance premium (Greenbaum and Thakor, 2007). To evade the problems, IDIC should consider using a fairer premium, which based on the risk (risk-based premium). Second, larger banks seem to have self-control mechanism relating to risk since they reduce risk position as their size increase. This finding highlights the importance of bank consolidation through Merger and Acquisition $(M \& A)$, and the authority should provide proper incentive for this. To preserve the competition and to maintain the contes table banking market, Bank Indonesia can open the door for new comer to take over the existing banks. Third, the bank excluding SOE banks tend to be more conservative to take risk as capital increase. Since this real phenomenon may arise as the form of capital preservation, the authority should emphasize the importance of capital along with the undergoing implementation of Basel III. 


\section{REFERENCES}

Apostolik. R., Donohue, C. And P. Went, 2009, Foundations of Banking Risk, Wiley Finance, New Jersey.

Boyd. J.H., and G. De Nicolo, 2005, "The Theory of Bank Risk Taking and Competition", The Journal of Finance, 60, No. 3, page 1239-1343.

Chan, Y.S, Greenbaum S.I., and A.V. Thakor, 1992, "Is Fairly priced deposits insurance possible?", Journal of Finance, 47, page 227-245.

Davidson, Russel, 2006, "Stochastic Dominance", Mc Gill University, Department of Economics Discussion Paper.

Freixas. X and Rochet J.C., 2008, Microeconomics of Banking, $2^{\text {nd }}$ Edition, MIT Press.

Gale, D. and M. Hellwig, 1985, "Incentive compatible debt contracts: the one period problem, Review of Economic Studies, Vol. 52, page 647-663.

Galloway, T.M., Lee W.D., and D.M. Roden, 1997, "Banks changing incentives and opportunities", Journal of Banking and Finance, 119, page 929-970.

Gennote, G and D. Pyle., 1991, "Capital control and bank risk", Journal Of Banking and Finance, 15, page 805-824.

Gorton, G., 1985, "Banks suspension of convertibility", Journal Of Monetary Economics, 15, page 177-193.

Greenbaum, S.I and A. Thakor, 2007, Contemporary Financial Intermediation, Academic Press, San Diego California.

Indonesia Deposit Insurance Corporation, Annual Report, 2009.

Innes, R.D., 1990, "Limited liability and incentive contracting with ex-ante action choices", Journal of Economic Theory, Vol. 52, page 45-67.

Hart, O., and Moore, 1994, "A theory of debt based on the inalienability of human capital", Quarterly Journal of Economics, Vol. 109, page 841-879.

Holstrom, B., 1979, "Moral hazard and Observability", Bell Journal of Economics, Vol. 10, page 74-91. 
Jappelli, M., Pagano, P., and M. Bianco, 2005, "Courts and banks: Effects of judicial enforcement on credit markets", Journal of Money, Credit and Banking, Vol. 37, page 223-244.

Lin, S.L. and Wu, S.J., 2005, "Capital requirements and Risk Taking Behavior in Banks: International Evidence", ISFA, Working Paper.

Marco-Garcia, T., and M.D. Fernandez-Robles, 2008, "Risk-taking behavior and ownership in the banking industry: The Spanish evidence", Journal of Economics and Business, 60, page 332-354.

Marcus, A.J., 1984, "Deregulation and Bank Financial Policy", Journal of Banking and Finance, Vol. 8., page 557-565.

Matutes, C. and X. Vives, 2000, "Imperfect Competition, risk taking and regulation in banking", European Economic Review, 44, page 1-34.

Jeitschko, T.D. and S.D. Jeung, 2005, "Incentives for Risk Taking in Banking-A Unified Approach", Journal of Banking and Financial, 29, page 759-777.

Saunders, A. and M.M. Cornett, 2003, Financial Institutions Management: A Risk Management Approach, McGraw Hill, Singapore.

Saunders, A., Strock, E., and N.G. Travlos, 1990,"Ownership Structure, Deregulation and Bank Risk Taking", The Journal of Finance, Vol. 45, No. 2, page 643-654.

Suarez, J., 1993,"Closure rules, market power and risk taking in a dynamic model of bank behavior", Discussion Paper, Universidad Carlos III, Madrid.

Townsend, R, 1979, "Optimal contracts and competitive markets with costly state verification", Journal of Economic Theory, Vol. 21, page 265-293.

Wilson, R, 1968, "On the theory of syndicates", Econometrica, Vol. 36, page 119-132. 